\title{
Innovation and Technological Upgrading in Lahore: Results From the LCCI Business Confidence Survey 2016
}

\section{Mahvish Faran* and Azam Chaudhry ${ }^{* *}$}

\begin{abstract}
The Lahore School of Economics and the Lahore Chamber of Commerce and Industry (LCCI) conducted a unique business confidence survey of firms in March 2015. The objective of the survey was to determine industry-specific trends as well as firms' perceptions of general macroeconomic trends. In 2016, the Lahore School and LCCI conducted a second business confidence survey in which they asked a sample of firms about the same issues as well as their level of innovation and technological upgrading. In this paper, we focus on the results of the innovation and technology component of the 2016 survey. We perform an aggregate analysis across firms to see if they have innovated and upgraded their technology. Next, we focus on the impact of innovation on exports and domestic sales to gauge whether firms reporting higher exports had innovated more. Finally, we look at each sector (manufacturing, services and retail) in turn and analyze the levels of innovation and technological innovation in each.
\end{abstract}

Keywords: Innovation, technology, macroeconomic trends, business confidence survey.

JEL classification: $\mathrm{O} 11, \mathrm{O} 14$.

\section{Introduction}

In March 2015, the Lahore Chamber of Commerce and Industry (LCCI) and the Lahore School of Economics signed a memorandum of understanding that established a link between academia and the business community. As part of this collaboration, the LCCI and the Lahore School conducted a business confidence survey of firms in order to determine industry-specific trends as well as general macroeconomic trends. The first survey was conducted in 2015 with a range of firms across three sectors: manufacturing, services and retail. The results of the survey indicated a cautious optimism among the business community.

\footnotetext{
${ }^{*}$ Visiting Lecturer, Lahore School of Economics.

** Professor and Dean of Economics, Lahore School of Economics.
} 
A few key messages emerged from the 2015 survey. First, between 2014 and 2015, firms grew in terms of sales, investment and size. Second, firms across all three sectors anticipated higher growth in 2015/16 and planned to increase their investment levels, expected to have further spillover effects on growth. Third, firms were extremely concerned about sources of financing and felt that the banking sector was falling far short of meeting their needs. Fourth, firms felt there were significant shortages in the pool of skilled labor, which was a major constraint to growth. Fifth, firms pointed to energy shortages as a major constraint to growth. Sixth, firms found both provincial and federal regulations and taxes extremely cumbersome and a significant drag on growth.

In 2016, the Lahore School and LCCI conducted a second business confidence survey in which they asked a sample of firms about the same issues as well as their level of innovation and technological upgrading. The reason for including questions on innovation and technology was to see if the optimism expressed by firms in the previous year's survey was followed by investments in innovation and technology and then to see which areas firms had focused on in terms of these investments.

In this paper, we focus on the results of the innovation and technology component of the 2016 survey. First, we perform an aggregate analysis across firms to see if they innovated and upgraded their technology. Then, we focus on the impact of innovation on total exports and domestic sales to see if firms reporting higher total exports and higher domestic sales had innovated more. We look at each sector in turn (manufacturing, services and retail) and gauge the levels of innovation and technological innovation therein.

An important point is whether growth leads to innovation or if innovation is an important element for growth. Is innovation a necessary condition for growth or is it an outcome of growth? It is interesting to see which areas account for the most innovation among firms that reported higher revenues. We also look at whether innovative firms have increased investment spending and whether firms with higher investment spending have innovated. Finally, we see if there is any relationship between bank borrowing and innovation and which key areas of innovation emerge among firms that acquired larger bank loans. 


\section{What Was Measured in This Year's Business Confidence Survey?}

The 2015 and 2016 Lahore School and LCCI business confidence surveys were administered online and asked firms to respond to questions on:

- Firm-level sales last year and expected sales the next year

- Firm-level investment undertaken last year and expected investment the next year

- Firm-level employment last year and expected employment the next year

- Firm-level bank borrowing last year and expected bank borrowing in the current year

- The impact of factors such as energy, access to finance, law and order and foreign competition

- The impact of provincial and federal regulations.

The 2016 survey asked firms the following:

- Had they innovated last year and were they planning to innovate next year?

- In what areas of business (production, marketing, finance) were firms innovating?

- Had they upgraded their technology last year and did they plan to upgrade their technology next year?

- In what areas of business (production, marketing, finance) were firms upgrading their technology?

- How do firms find out about innovations and new technologies?

An important distinction was made between innovation and technological innovation. When asking questions about innovation, the survey referred to the introduction of a new or significantly improved product, process, organizational method, technology upgrade or marketing method. These innovations would have been new to the firm, but may have been originally developed by other enterprises. The questions on technological upgrading focused purely on whether firms had invested in new technologies. 
The reason for this distinction is that innovation is a far wider concept than merely technological innovation and it was important to capture whether firms were innovating even with their existing technologies. On the other hand, given the importance of technological upgrading when discussing firm-level productivity improvements, the survey also asked questions about technological upgrades as opposed to innovation.

\section{Innovation and Technological Upgrading Across All Firms}

We start by looking at the level of innovation and technology upgrading across all firms surveyed in 2016. Figure 1 shows that 72 percent of firms reported engaging in innovation last year. The breakdown of these innovations is presented in Figure 2, which shows that most innovations were carried out in production and marketing.

Figure 1: Did your firm engage in any innovation last year (all firms)?

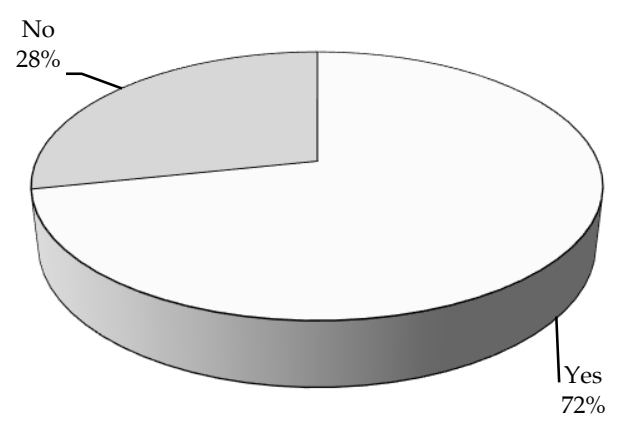

Figure 2: If so, in which areas did you innovate (all firms)?

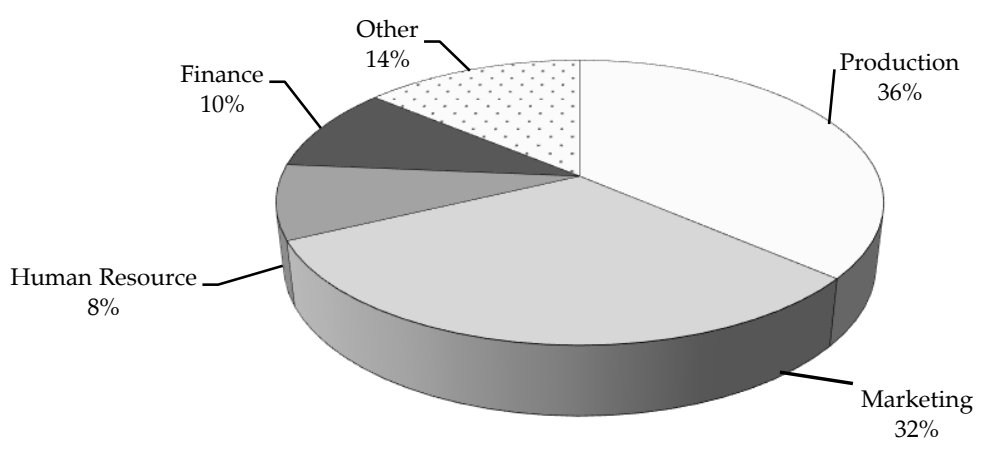

Figure 3 shows that 75 percent of firms engaged in technological upgrading last year. Figure 4 shows the breakdown of areas in which these 
technological innovations occurred. Again, the majority of technological innovation focused on products and marketing.

Figure 3: Did you upgrade your technology as a part of innovation (all firms)?

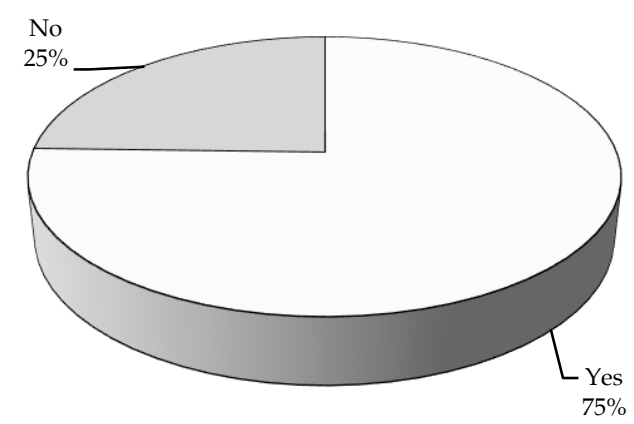

Figure 4: In which areas did you upgrade your technology (all firms)?

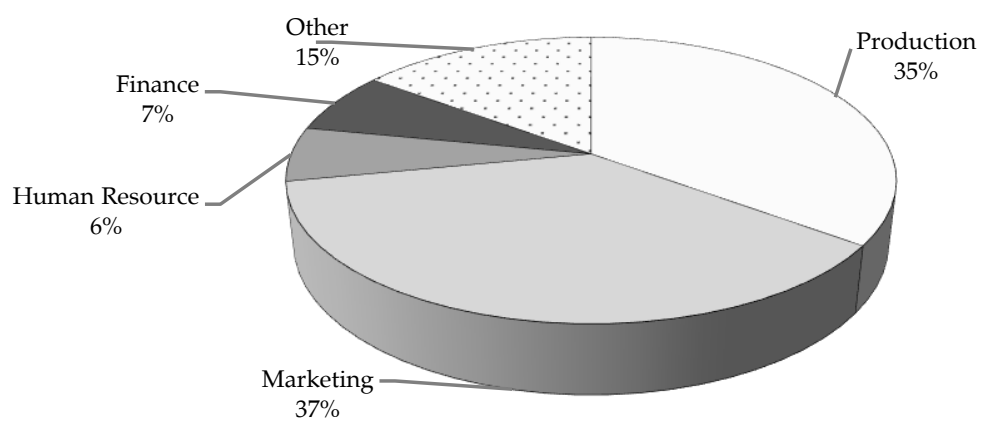

When asked whether they planned to upgrade their technology this year, a significant majority (85 percent) said yes (Figure 5). The responses show that more firms planned to upgrade their technology this year compared to last year.

Figure 5: Do you plan to upgrade your technology this year (all firms)?

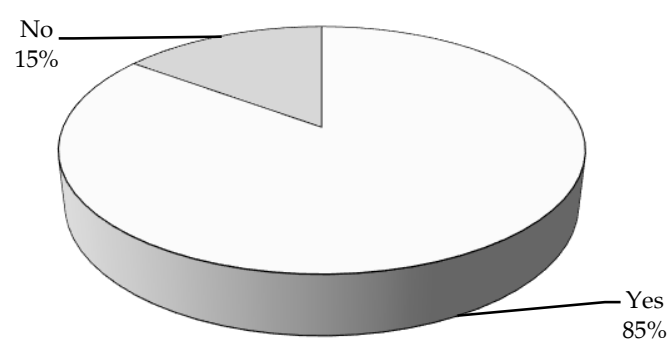


Figure 6 shows that most firms planned to improve their technologies in production and marketing, but this combined percentage is smaller than in the previous breakdown (shown in Figure 4). This implies that firms may have begun focusing on upgrading technologies in other areas, such as human resources and finance.

Figure 6: In which areas do you plan to upgrade your technology (all firms)?

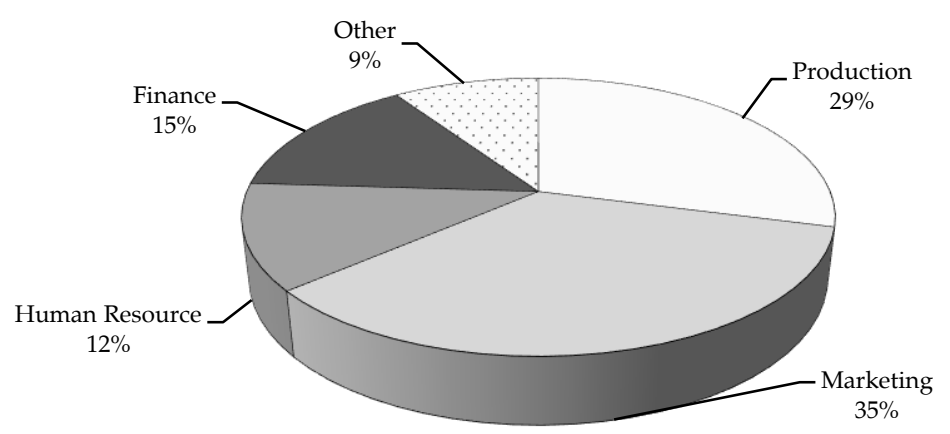

Finally, firms were asked how they learned about new technologies (Figure 7). What is interesting here is that a significant number of firms say they learned about new technologies and innovations from the Internet, exhibitions and customers. A very small percentage cited research, academic and public sector institutions, which reflects the latter's failure to connect with firms. What is also interesting is that firms reported very little spillover between firms in terms of technologies and innovations, implying that there is very little cooperation among firms.

Figure 7: How do you learn about new technologies and innovations (all firms)?

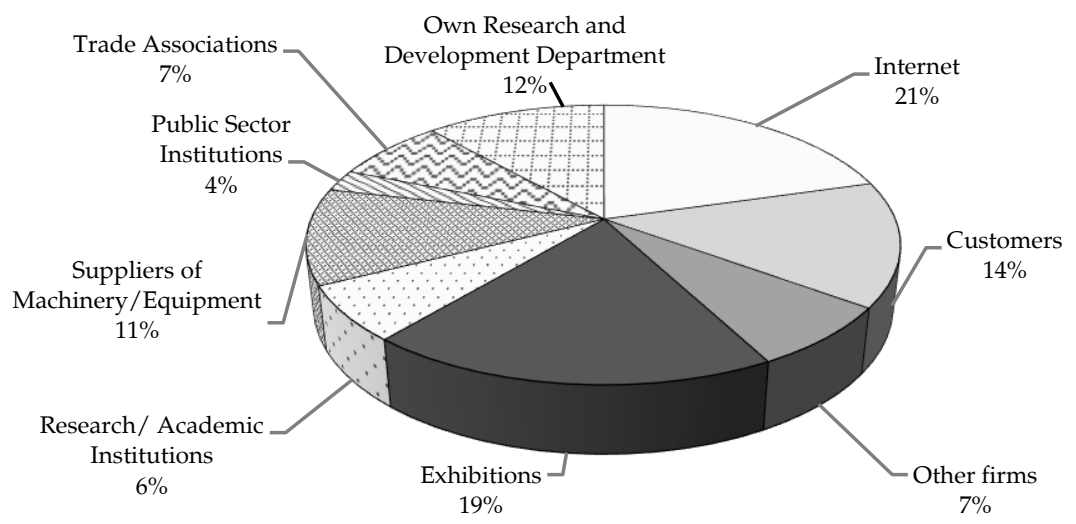


On the whole, a much larger proportion of firms had innovated and upgraded their technology and planned to continue innovating this year, which seems to imply that Pakistani firms are far from stagnant in terms of innovation. What is interesting is that the bulk of technological upgrading took place in marketing, followed closely by upgrading in production; firms planned to continue focusing on these areas. Finally, firms reported finding out about innovations from the Internet, customers and exhibitions. This reflects the need to focus on creating opportunities for them to access these sources more easily. It also illustrates the failure of research, academia and the government to promote innovative ideas.

\section{Innovation and Technological Upgrading in Manufacturing}

Figures 8 and 10 show that a significant majority of manufacturing firms (81 percent) said they had engaged in innovation and technological upgrading last year - this number is higher than the average across firms. Figures 9 and 11 show that manufacturing firms focused almost all their innovation and technological upgrading in production and marketing.

Figure 8: Did your firm engage in any innovation last year (manufacturing firms)?

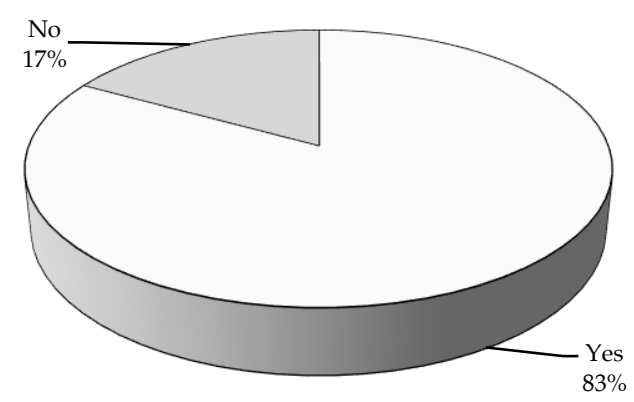

Figure 9: If so, in which areas did you innovate (manufacturing firms)?

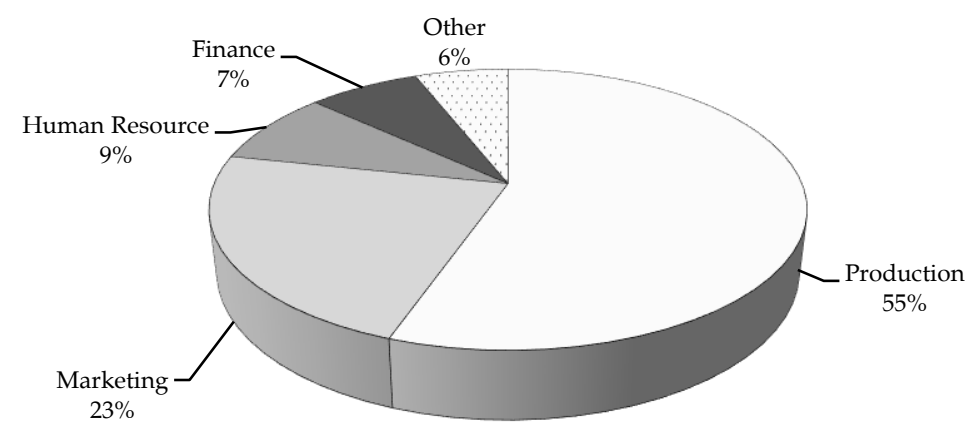


Figure 10: In which areas did you upgrade your technology (manufacturing firms)?

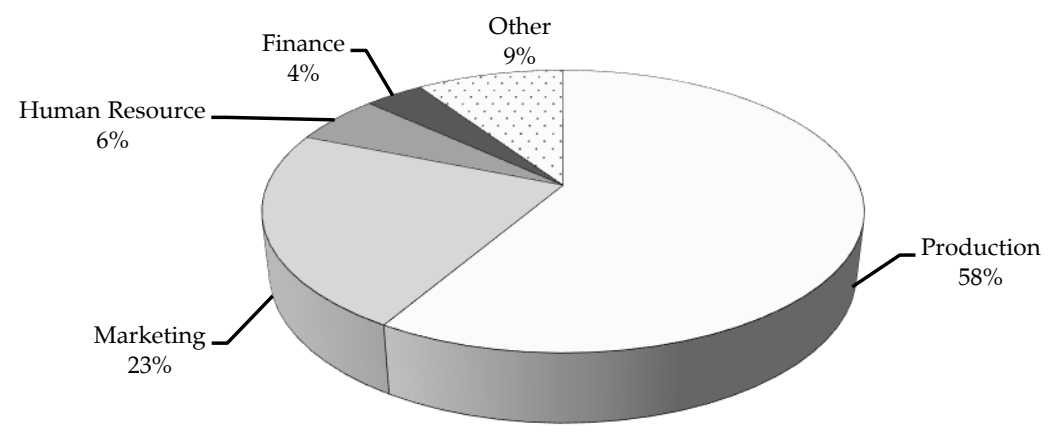

Figure 11: Did you upgrade your technology as a part of innovation (manufacturing firms)?

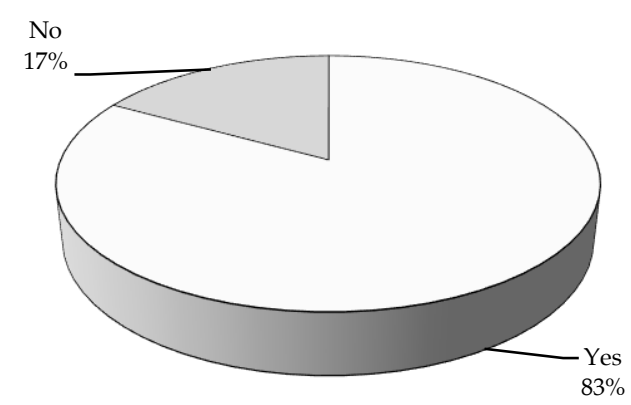

When asked about the current year, 88 percent of manufacturing firms said they planned to upgrade their technologies (Figure 12). Again, the vast majority planned to focus on production and marketing in this context, continuing the trend from the previous year (Figure 13).

Figure 12: Do you plan to upgrade your technology this year (manufacturing firms)?

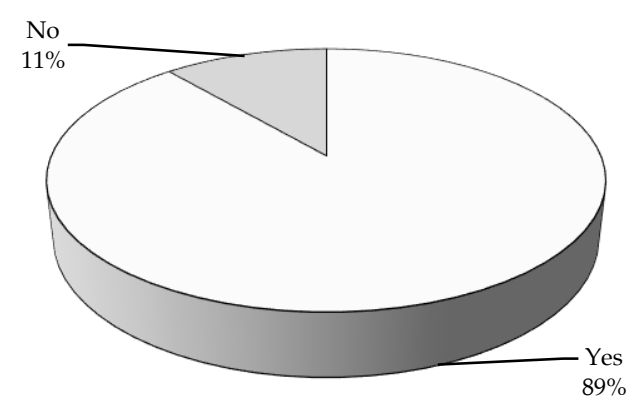




\section{Figure 13: In which areas do you plan to upgrade your technology (manufacturing firms)?}

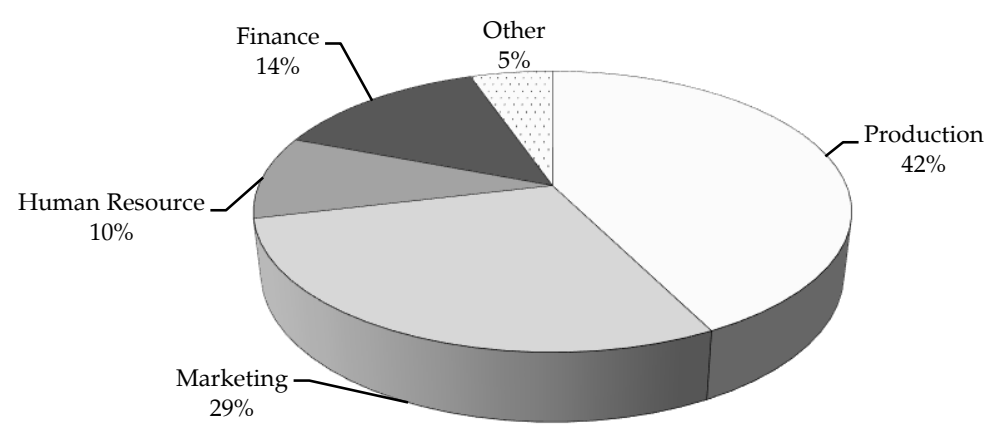

Figure 14 shows how manufacturing firms find out about innovations and new technologies. Their key sources include the Internet, customers and exhibitions as well as suppliers of machinery. This shows that the same sources of information for most firms overall are as relevant to manufacturing firms. Machinery suppliers are also a critical source of information for the latter.

\section{Figure 14: How do you learn about new technologies and innovations (manufacturing firms)?}

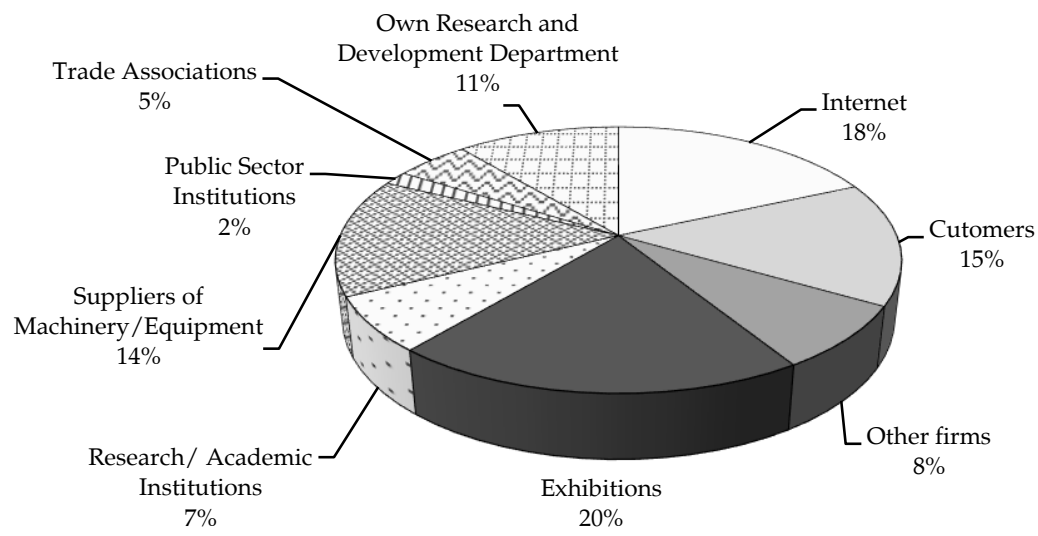

It is useful to point out the differences between the results for the manufacturing sector and the results for firms overall. The vast majority of manufacturing firms innovated and upgraded their technology in production and planned to continue focusing on this aspect (though they were also innovating on the marketing side). While manufacturing firms tend to rely on the Internet, exhibitions and customers for information, they also report obtaining information about technologies and innovation 
from their suppliers of machinery. This points to policies that allow manufacturers greater interaction with international suppliers of machinery (which could be as close as suppliers in India).

\section{Innovation and Technological Upgrading in Services}

While the rate of innovation in the services sector is similar to that of the manufacturing sector, the nature of innovation and technology upgrading in the former is fundamentally different. Figures 15 and 17 show that a significant number of firms in the services sector innovated and upgraded their technology (this percentage is not significantly different from firms in the manufacturing sector). At the same time, the services sector differs in the areas in which it upgraded its technology. Figure 16 shows that services sector firms focused much of their innovation on marketing, followed by production and other areas. Figure 18 shows that, in the previous year, the vast majority of technological upgrading occurred in marketing. This implies that services sector firms focus their new technologies on marketing, but remain innovative across the board.

Figure 15: Did your firm engage in any innovation last year (services firms)?

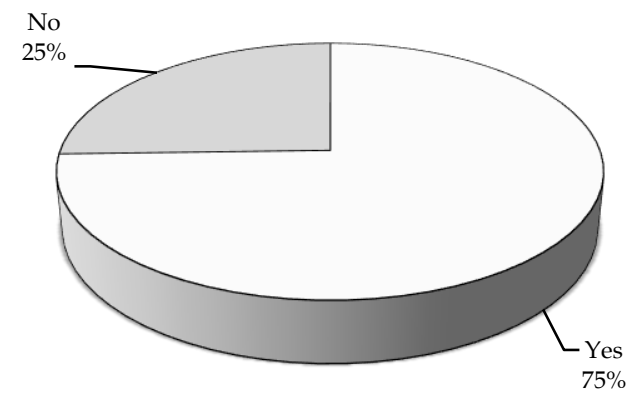

Figure 16: If so, in which areas did you innovate (services firms)?

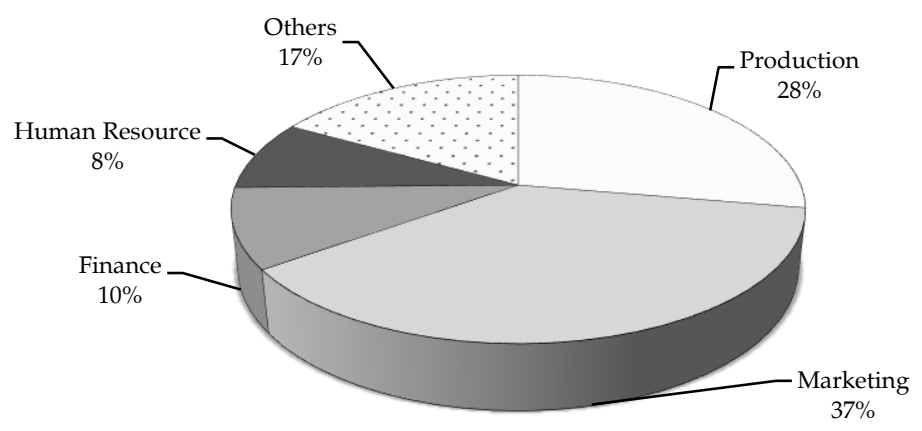


Figure 17: Did you upgrade your technology as a part of innovation (services firms)?

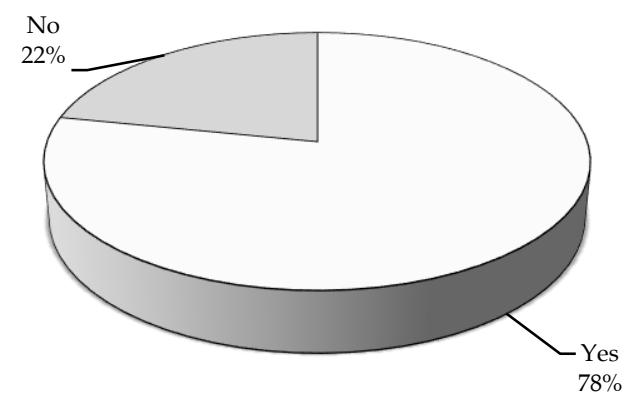

Figure 18: In which areas did you upgrade your technology (services firms)?

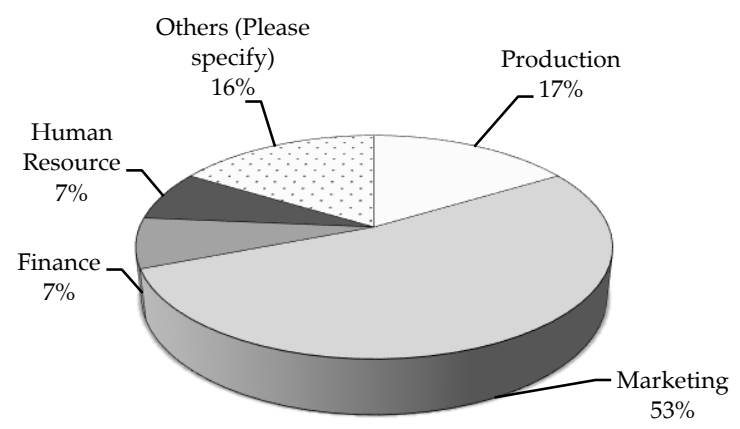

Figures 19 and 20 show the sector's plans for technological upgrading in the current year. What is interesting is that a very high percentage of firms plan to upgrade their technology across a group of areas as well as upgrading their technology in marketing (as in the previous year).

Figure 19: Do you plan to upgrade your technology this year (services firms)?

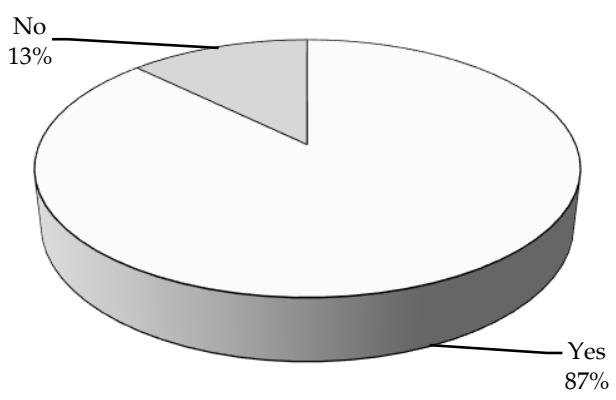


Figure 20: In which areas do you plan to upgrade your technology (services firms)?

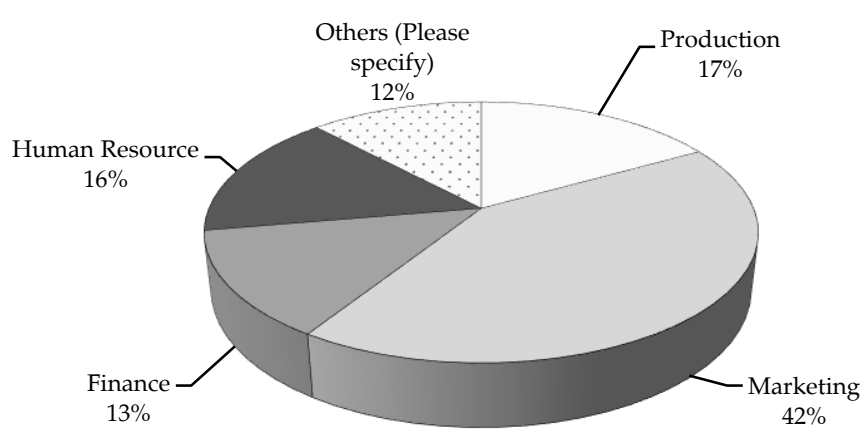

Figure 21 shows that services sector firms cite the same sources of information as manufacturing firms: the Internet, customers and exhibitions. A significant number also point to their own research, which implies that these firms engage in far more (productive) research than firms in the manufacturing sector.

Figure 21: How do you learn about new technologies and innovations (services firms)?

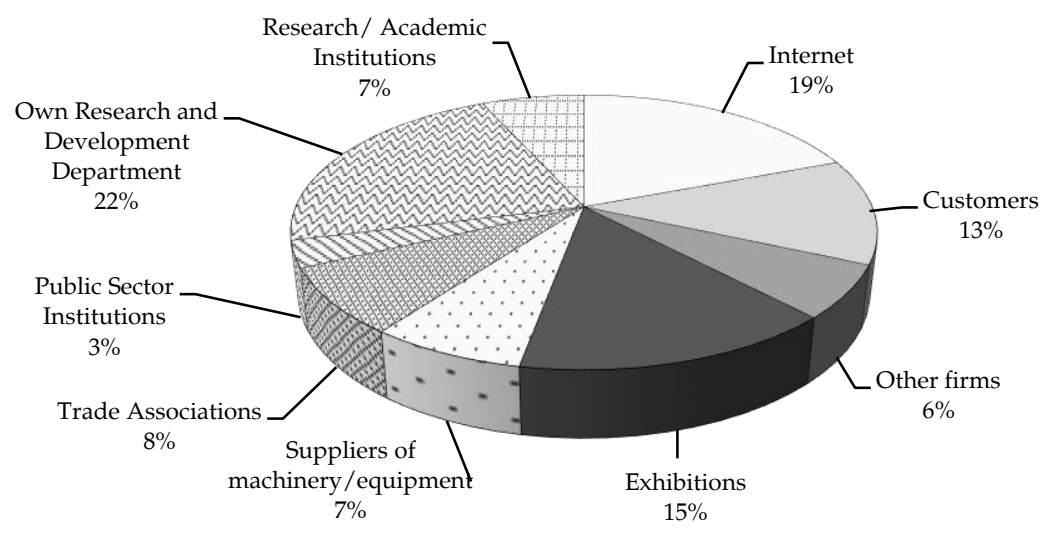

As expected, the bulk of innovation and technology upgrading took place on the marketing side and firms plan to increase their focus on this area in the current year. Unlike the manufacturing sector, the services sector also focuses on innovation and technology upgrading in areas such as finance and human resources. In terms of sources of information, the services sector relies on the same sources as other sectors - the Internet, customers and exhibitions - but, unlike the manufacturing sector, it also depends on its own research and development (R\&D) for innovations. 


\section{Innovation and Technological Upgrading in Retail}

The retail sector seems to be different in terms of innovation and technological innovation compared to the other sectors. Figures 22 and 24 show that, while a significant number of retail firms say they innovated and upgraded their technology last year, this percentage is lower than that of the manufacturing and services sectors.

Figures 23 and 25 show which areas the surveyed retail firms focused on when innovating and upgrading their technologies. Retail firms have a relatively even distribution of innovations across areas such as marketing, human resources and production (and this is more evenly spread than in other sectors). What is interesting is that, while retail firms improved their technologies in areas such as marketing and production, a significant proportion also focused on finance - unlike the other sectors.

Figure 22: Did your firm engage in any innovation last year (retail firms)?

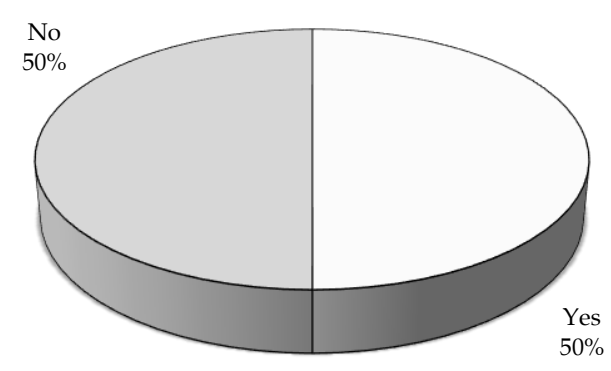

Figure 23: If so, in which areas did you innovate (retail firms)?

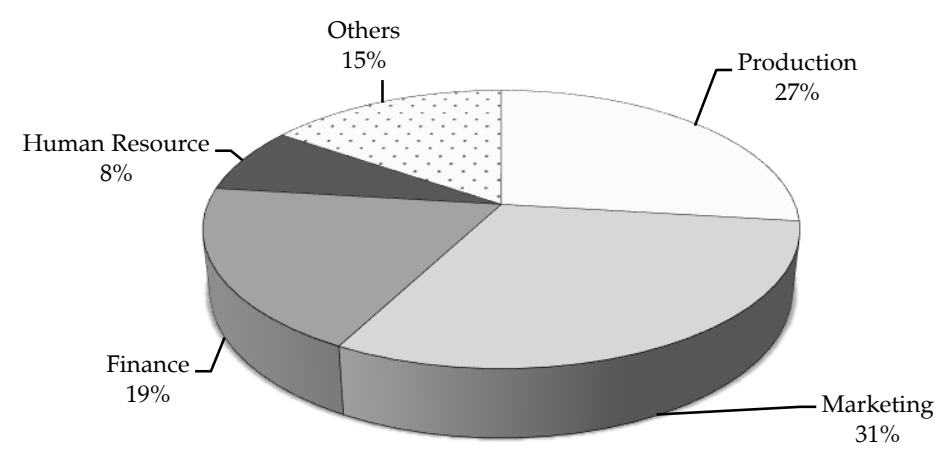


Figure 24: Did you upgrade your technology as a part of innovation (retail firms)?

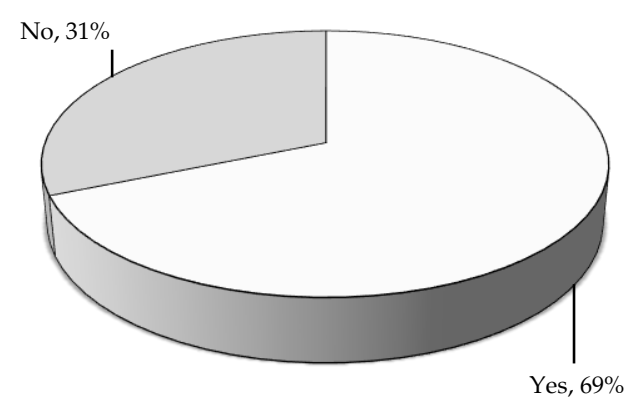

Figure 25: In which areas did you upgrade your technology (retail firms)?

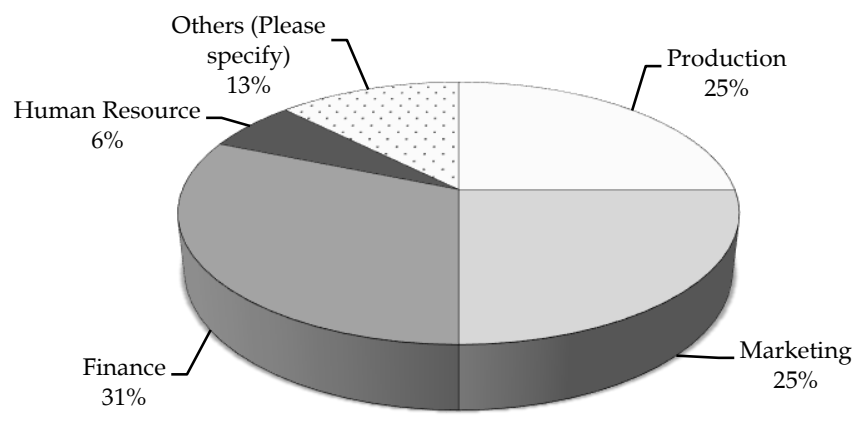

Figures 26 and 27 show that all retail firms plan to improve their technologies in the current year, focusing on production, marketing and finance.

Figure 26: Do you plan to upgrade your technology this year (retail firms)?

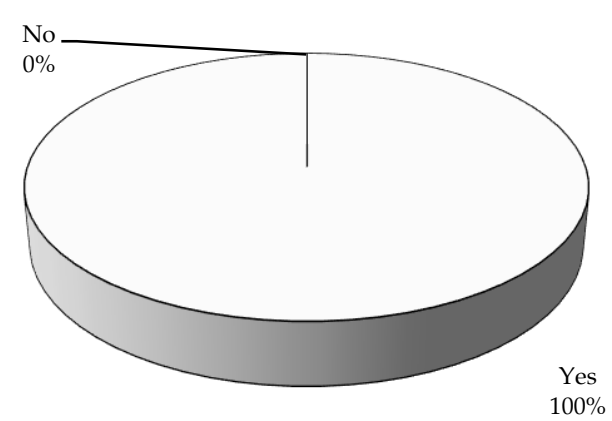


Figure 27: In which areas do you plan to upgrade your technology (retail firms)?

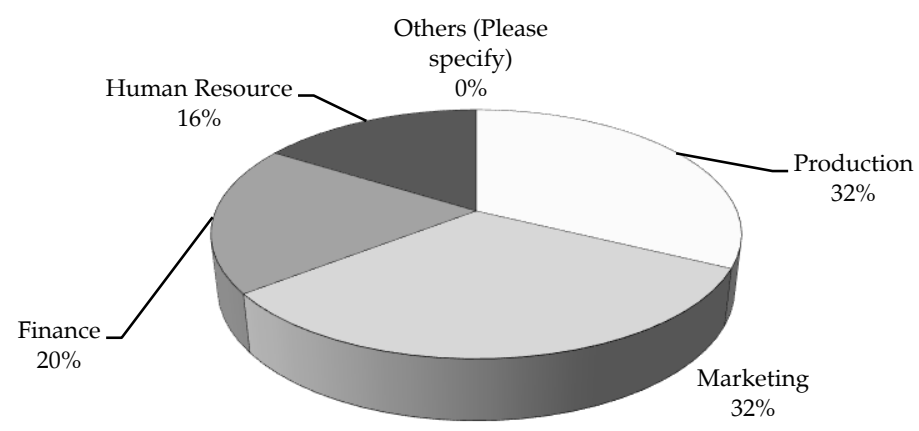

Figure 28 shows that retail firms benefit from the same sources of information as firms in other sectors, such as the Internet, customers and exhibitions. However, a significant number of firms cite suppliers of machinery and trade associations as important sources of information on technology and innovation.

Figure 28: How do you learn about new technologies and innovations? (retail firms)

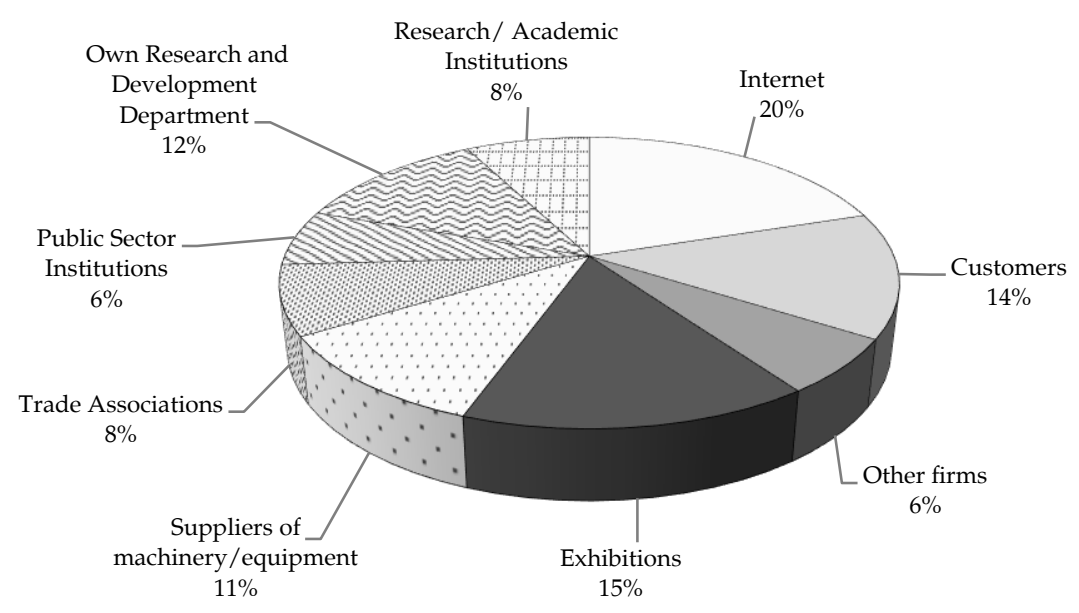

Innovation and technology upgrading in the retail sector occur far more evenly across areas such as marketing, human resources and production. Retail firms plan to continue this diverse investment in the coming year. Their sources of information on new innovations and technologies follow the same general trend: most information flows come from the Internet, customers, exhibitions and suppliers of machinery. 


\section{Gains to Innovative Firms}

One of the objectives of the survey was to determine if innovative firms had grown over the last year. Table 1 shows the benefits to firms that reported having innovated in the last year. A significant proportion of firms that innovated report higher total sales and domestic sales, but only 30 percent report higher export revenues. In terms of investment and bank borrowing, 72 percent of the firms that innovated report higher investment in the previous year, while only 22 percent report higher bank borrowing. The implication is that most gains from innovation and technological upgrading came from higher domestic revenues. Also, while innovative firms increased investment, very little of this came from bank borrowing.

Table 1: Firms that innovated last year

\begin{tabular}{ll}
\hline$\%$ of innovative firms whose total revenues increased & 58 \\
$\%$ of innovative firms whose domestic revenues increased & 59 \\
$\%$ of innovative firms whose export revenues increased & 30 \\
$\%$ of innovative firms whose investment increased & 72 \\
$\%$ of innovative firms whose bank borrowing increased & 22 \\
\hline
\end{tabular}

The results for technology upgrading are similar. Table 2 shows that, of the firms that upgraded their technology, 58 percent report higher total revenues, 56 percent report higher domestic revenues and only 32 percent report higher export revenues. While 66 percent of the firms that upgraded their technology report higher investment, only 22 percent report higher bank borrowing.

\section{Table 2: Firms that upgraded their technology last year}

\begin{tabular}{ll}
\hline \% of firms that upgraded technology whose total revenues increased & 58 \\
\% of firms that upgraded technology whose domestic revenues increased & 56 \\
\% of firms that upgraded technology whose export revenues increased & 32 \\
\% of firms that upgraded technology whose investment increased & 66 \\
\% of firms that upgraded technology whose bank borrowing increased & 22 \\
\hline
\end{tabular}

Tables 3 and 4 give the results for those firms that innovated in production and marketing, respectively. While they experienced about the same increase in total revenues and domestic revenues as other firms that innovated, 30 percent of those reporting production innovations had higher export revenues and 28 percent of firms that innovated in marketing experienced higher export growth. Almost eight out of every ten firms that 
innovated in production report higher investment. In terms of bank borrowing, there is a stark contrast between those that innovated on the production side and those that innovated on the marketing side: 33 percent of the firms that innovated in production report higher bank borrowing (which is significantly above the average across all firms and those firms that innovate). Only 19 percent of the firms with marketing innovations report higher bank borrowing.

\section{Table 3: Firms that innovated in production}

\begin{tabular}{ll}
\hline$\%$ of innovative firms whose total revenues increased & 56 \\
$\%$ of innovative firms whose domestic revenues increased & 56 \\
$\%$ of innovative firms whose export revenues increased & 30 \\
$\%$ of innovative firms whose investment increased & 76 \\
$\%$ of innovative firms whose bank borrowing increased & 33 \\
\hline
\end{tabular}

Table 4: Firms that innovated in marketing

\begin{tabular}{ll}
\hline$\%$ of innovative firms whose total revenues increased & 50 \\
$\%$ of innovative firms whose domestic revenues increased & 50 \\
$\%$ of innovative firms whose export revenues increased & 28 \\
$\%$ of innovative firms whose investment increased & 59 \\
$\%$ of innovative firms whose bank borrowing increased & 19 \\
\hline
\end{tabular}

These results echo those for all firms that innovated. Most firms that innovated on the production side last year had higher domestic revenues and almost three quarters increased their investment. A major difference is that firms that innovated in production had a significantly higher level of bank borrowing than the average firm, implying that they either had greater access to bank borrowing or were more willing to borrow from banks than other firms. Fewer firms that innovated in marketing increased investment and the proportion of these that borrowed from banks is lower than the average.

\section{Did Growing Firms Innovate?}

Tables 5-7 show whether growing firms tend to innovate and in which areas they do so. We see that the vast majority of firms that experienced higher total sales, higher domestic sales and higher export sales innovated and upgraded their technology. While 82 percent of the firms reporting higher total sales and 44 percent reporting higher domestic sales innovated in production, 58 percent of the firms reporting higher 
export sales innovated in production. Only 45 percent of the firms that reported higher export sales innovated on the marketing side.

\section{Table 5: Firms that reported higher total sales}

$\%$ of firms with higher total sales that innovated 82

$\%$ of firms with higher total sales that upgraded technology 87

$\%$ of firms with higher total sales that innovated in production 59

$\%$ of firms with higher total sales that innovated in marketing 45

\section{Table 6: Firms that reported higher domestic sales}

\begin{tabular}{ll}
\hline$\%$ of firms with higher domestic sales that innovated & 85
\end{tabular}

$\begin{array}{ll}\% \text { of firms with higher domestic sales that upgraded technology } & 87\end{array}$

$\%$ of firms with higher domestic sales that innovated in production $\quad 44$

\% of firms with higher domestic sales that innovated in marketing $\quad 27$

\section{Table 7: Firms that reported higher export sales}

\begin{tabular}{ll}
\hline$\%$ of firms with higher export sales that innovated & 75 \\
$\%$ of firms with higher export sales that upgraded technology & 85 \\
$\%$ of firms with higher export sales that innovated in production & 58 \\
$\%$ of firms with higher export sales that innovated in marketing & 45
\end{tabular}

These tables imply that firms that experienced growth due to higher domestic sales innovated more than firms that experienced growth in export sales.

\section{Did Firms That Increased Investment Innovate?}

As Table 8 shows, 84 percent of the firms reporting higher investment innovated, while 83 percent upgraded their technology. Of those firms that report higher investment, 44 percent innovated in production while 32 percent innovated in marketing.

Table 8: Firms that reported higher investment

\begin{tabular}{ll}
\hline$\%$ of firms with higher investment that innovated & 84 \\
$\%$ of firms with higher investment that upgraded technology & 83 \\
$\%$ of firms with higher investment that innovated in production & 44 \\
$\%$ of firms with higher investment that innovated in marketing & 32 \\
\hline
\end{tabular}




\section{Did Firms That Increased Their Bank Borrowing Innovate?}

The survey reveals that, over the last two years, a very small percentage of firms reported higher bank borrowing. Of these, about 75 percent innovated and about 79 percent upgraded their technology. Moreover, 83 percent of the firms with higher bank borrowing reported innovations in production while only 42 percent reported innovations in marketing (Table 9).

Table 9: Firms that reported higher bank borrowing

\begin{tabular}{ll}
\hline \% of firms with higher bank borrowing that innovated & 75 \\
\% of firms with higher bank borrowing that upgraded technology & 79 \\
\% of firms with higher bank borrowing that innovated in production & 83 \\
\% of firms with higher bank borrowing that innovated in marketing & 42 \\
\hline
\end{tabular}

\section{How did Common Constraints Affect Innovation?}

The survey asked firms about the impact of major constraints to business in Pakistan, including energy shortages, access to finance, foreign competition and poor law and order. We gauge whether firms that cited these constraints innovated less or more. In the first case, such factors may have reduced their incentive to innovate, the resources devoted to innovation or the perceived benefits of innovation. In the second case, firms may have needed to innovate more to remain competitive under such constraints.

Table 10 shows that almost three quarters of the surveyed firms facing energy shortages, poor access to finance, foreign competition and weak law and order innovated over the last year. This suggests that firms innovated despite, or possibly because of, these constraints.

Table 10: Impact of common constraints on innovation

\begin{tabular}{lc}
\hline $\begin{array}{l}\text { \% of innovative firms that said energy was a major factor affecting } \\
\text { their business }\end{array}$ & 74 \\
$\%$ of innovative firms that said access to finance was a major factor & 67 \\
$\begin{array}{l}\text { affecting their business } \\
\% \text { of innovative firms that said foreign competition was a major factor }\end{array}$ & 52 \\
$\begin{array}{l}\text { affecting their business } \\
\% \text { of innovative firms that said law and order was a major factor }\end{array}$ & 67 \\
affecting their business & \\
\hline
\end{tabular}


Interestingly, even though energy is commonly perceived as a binding business constraint, the percentage of firms that cited energy as a major constraint to innovation also felt that access to finance, followed by law and order and foreign competition, were important constraints. This means that efforts to reduce energy constraints without focusing on other issues such as access to finance, foreign competition and law and order will not result in higher innovation in the economy.

\section{Sources of Innovation for Growing Firms}

How do sources of innovation vary among firms that are expanding because of higher domestic sales and those that are expanding due to higher export sales? Figure 29 shows that firms whose growth is due to higher domestic sales rely on the Internet, customers, exhibitions, their own R\&D departments and suppliers of machinery and equipment for innovation-related information. Figure 30 shows that firms with expanding export sales depend on customers, exhibitions, the Internet and their own R\&D departments.

Here, we see that firms with higher domestic sales access the Internet, customers and exhibitions as their major sources of innovation. On the other hand, firms with higher export sales rely mainly on exhibitions, customers and the Internet, followed by their own R\&D.

\section{Figure 29: Sources of innovation for firms that reported higher domestic sales}

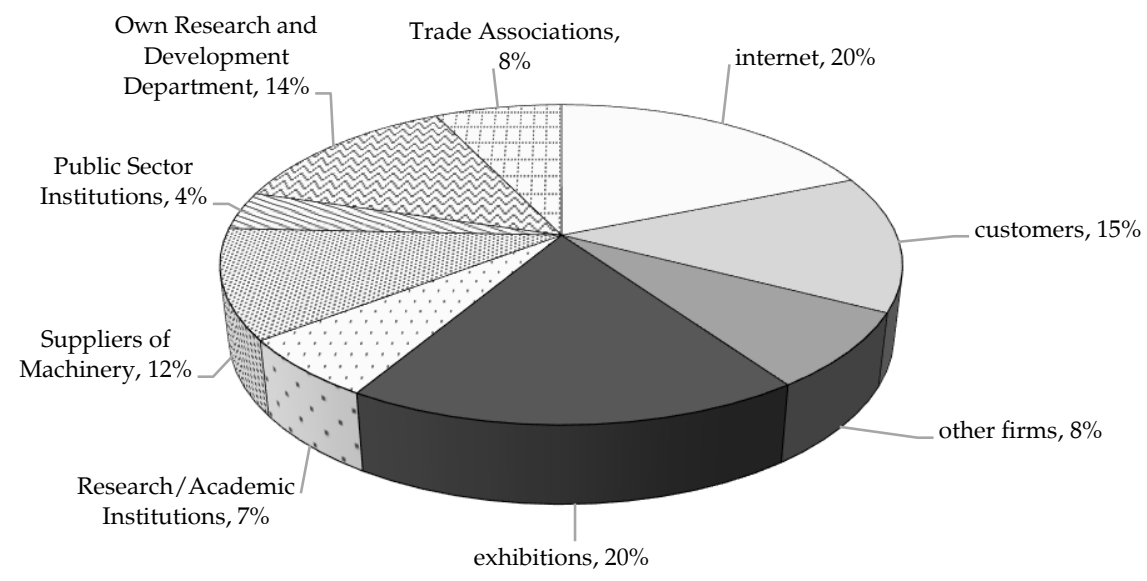




\section{Figure 30: Sources of innovation for firms that reported higher export} sales

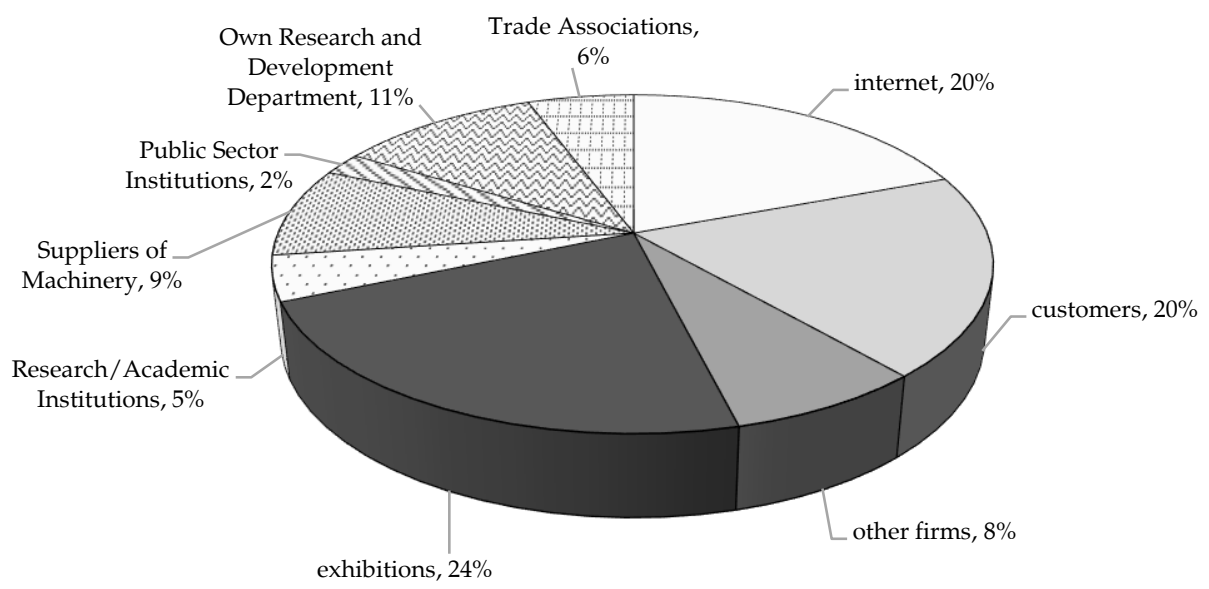

\section{Conclusion}

The key results of the survey are presented in this section.

The results show that 72 percent of the responding firms engaged in innovation last year, primarily in production and marketing. Firms seem optimistic about upgrading their technology in the future, with production and marketing as their key areas of focus. Most firms plan to upgrade their technology (85 percent), primarily in production and marketing. The vast majority of manufacturing firms have focused on innovating and upgrading their technology in production and plan to continue focusing on these aspects, although they are also innovating on the marketing side.

While manufacturing firms obtain information on innovations from the Internet, exhibitions and customers, they also rely on their suppliers of machinery. In the services sector, the bulk of innovation and technology upgrading took place on the marketing side and firms plan to increase their focus on this in the current year. Unlike the manufacturing sector, the services sector is also focusing on innovation and technology upgrades in other areas such as finance and human resources. Innovation and technology upgrading in retail is far more even across areas such as marketing, human resource management and production. Retail firms plan to continue this diverse investment in the coming year. 
Learning about innovation and technology upgrades from customers, the Internet and exhibitions seems to be the norm among the sample of firms, especially for the manufacturing and services sectors. However, trade associations and suppliers of machinery are also important sources of information for the retail sector. This implies that academic, research and public sector institutions have failed to form a strong connection with firms. There seems to be little technological spillover between firms. The services sector is ahead of the manufacturing and retail sectors in terms of indigenous innovation, with 22 percent of firms learning about new technology and innovation through their own R\&D.

Most firms that innovated on the production side last year had higher domestic revenues and almost three quarters increased investment. At the same time, a major difference is that firms innovating in production had a significantly higher level of bank borrowing than the average firm, implying that firms that focused on upgrading their production either had greater access to bank borrowing or were more willing to borrow from banks than other firms. This differential could be attributed to the fact that obtaining a bank loan for upgrading machinery or other essential items for production may be easier than obtaining a loan to launch a new advertisement campaign. On the other hand, fewer firms that innovated on the marketing side increased investment and the proportion of these firms that borrowed from banks was lower than the average.

An interesting question is whether growth leads to innovation or if innovation leads to growth. The results indicate that 82 percent of firms reporting higher revenues innovated compared to 58 percent reporting higher sales. About 75 percent of firms reporting higher export revenues engaged in innovation compared to only 30 percent of innovative firms reporting higher export sales, while 59 percent with higher export revenues had innovated in production and 45 percent in marketing.

While energy is perceived as a key binding constraint for firms, the percentage of firms that cited energy shortages as a major constraint to innovation also mentioned access to finance as an important impediment, followed by foreign competition and law and order. This means that reducing energy constraints without focusing on issues such as access to finance, foreign competition and law and order will not result in higher innovation in the economy.

Firms with higher domestic sales cited the Internet, customers and exhibitions as their major sources of innovation, followed by their own 
R\&D departments. Firms with higher export sales relied on customers, exhibitions and the Internet as their major sources of innovation.

To enhance the level of innovation in the industrial sector, research and academic institutions should be given incentives to disseminate their research and help bridge the gap between academia and industry. Public sector institutions should help industry in terms of building research capacity and resolving the challenges associated with new technology. Research and public sector institutions should provide a forum for firms to cooperate and share knowledge on innovations and new technologies. While the bulk of innovation and technology adoption is concentrated in production and marketing, both industry and other institutions should work together to explore sources of innovation and technology in other spheres as well. 